Review Article

\title{
Nationally Important Agricultural Heritage Systems in India: Need for Characterization and Scientific Validation
}

\author{
ANURUDH K SINGH ${ }^{1, *, \#}$ and RAI S RANA ${ }^{2}$ \\ ${ }^{1}$ Former Head, Division of Germplasm Conservation, NBPGR 110 012, India \\ ${ }^{2}$ Former Director, NBPGR, New Delhi 110 012, India
}

(Received on 09 August 2018; Revised on 09 October 2018; Accepted on 14 November 2018)

\begin{abstract}
Farm families and tribal communities have developed diverse locally adapted agricultural systems, around the world, which have been managed traditionally with time-tested skills and practices. While providing food and livelihood security to small scale farmers, these agricultural systems have also helped conserving genetic resources for food and agriculture. India is rich in traditional agricultural systems practised in its 20 agroecological zones. This paper briefly describes 48 of the systems which have potential for their global recognition under the FAO Initiative that began in 2002. The FAO has recognised 100 such systems/sites across 20 countries as Globally Important Agricultural Heritage Systems. India has recognition of three systems/sites while China and Japan have 15 and 11 systems/sites respectively. To get recognition to the promising agricultural heritage systems out of the suggested 48 , there is a need for more scientific studies aimed at their proper description and characterization based on the appropriate criteria set out for this purpose. This is essential, because most are being threatened by the modern agricultural practices and the important ones need to be protected and promoted for wider global use. This will help face the challenges of $21^{\text {st }}$ Century, ensuring facilitated access to genetic resources and associated knowledge with sharing of benefits accrued from their use.
\end{abstract}

Key words: Agriculture; Agricultural Biodiversity; Agricultural Practices; Agricultural Heritage System (AHS); Identification; Characterization; Evaluation; Conservation

\section{Introduction}

Specific agricultural systems and landscapes have been created, shaped and maintained worldwide, by generations of farmers and herders, providing food, nutritional and livelihood security, and maintenance of both natural and cultural diversity. Therefore, the Agricultural Heritage System (AHS) can be defined as remarkable unique land use systems and landscapes, evolved by local communities with coadaption of biological diversity and the surrounding environment in a profitable manner, meeting the livelihood requirements, needs and aspiration of locals for sustainable development of the region.

These systems can be source of alternative knowledge and information, which can help to improve agriculture and/or management of natural

*Author for Correspondence: E-mail: anurudhksingh@gmail.com

\#Present address: 2924, Sector-23, Gurugram, Haryana resources. Further, these systems are rich in agricultural biological diversity. Environment friendly science base of the traditional practices/systems facilitating conservation of natural resources has been the basis for sustainable agriculture over centuries, particularly in the developing countries. Therefore, integration of these features with recent biotechnological techniques can help in development of more innovative technologies, which can have global significance in overcoming constrains of similar ecologies and/or to meet the challenges of climate change and that of evolving $21^{\text {st }}$ Century.

India, being centre of some of the oldest civilizations, is no exception and harbours many AHS. Three AHS i.e., Cultivation of saffron heritage of Kashmir; Traditional agriculture of Koraput; and Below sea level farming system of Kuttanad, Kerala 
have been notified by Food and Agriculture Organization (FAO) as Globally Important Agricultural Heritage Systems between 2011-2013. However, many more need to be identified based on defined indices, studied by researchers representing relevant disciplines to enable their scientific characterization, potential evaluation, and documentation with a view to develop awareness and perspective value in improvement of agriculture and raise them to the level of global significance. The present article attempts to illustrate the indices that can be used in identification of AHS and bring probable AHS into scientific domain with brief description to stimulate research and in-depth studies for their detailed scientific characterization, assessment of potential value, to raise their significance globally for wider use and claim for a World Heritage tag from FAO. It becomes more essential under the present global IPR, and access and benefit sharing scenario on the use of genetic resources and traditional knowledge.

\section{Indian Subcontinent/India, a Host of Agricultural Heritage Systems}

Indian Subcontinent is one of the oldest centres of agriculture origin with earliest evidences of settled agriculture at Mehrgarh close to $7000 \mathrm{BC}$ or 6500 BC (Jarriage, 1984; Possehl, 1988) in two phases (Neolithic and Chalcolithic); recent discovery at Gulf of Khambhat also called Gulf of Cambay, perhaps as old as 7500 BC (Frawley, 2002), may be an ancient delta of the now dry Saraswati River and coastal origin, and/or a part of greater Saraswati region and culture; and the Neolithic settlements at Chopani Mando in Gangetic plains, Koldiwah and Mahagara in the Belan Valley in the Vindhyan Ranges adjoining Gangetic Plains with south ward movement into Madhya Pradesh. Further expansion of agriculture to other parts of the Indian Subcontinent with diverse ecologies led to development of many diverse, but unique agricultural heritage systems adapted to wide range of agro-climates. This phenomenon led to development of diverse agriculture and agricultural practices and evolution of several civilizations, such as Harappan Civilization renamed as Indus-Saraswati Civilization (Misra, 1994; Gupta, 1993, 1996, 2001) or Saraswati River Civilization (Kalyanaraman, 2001) and Gangetic Civilization as component of larger Vedic civilization or culture, with predominant agriculturebased economy.
The Indian Subcontinent is also unique, encompassing a wide range of ecological/climatic diversity starting from snow covered Himalayan Mountains to cold desert and alpine forests, from river plains to hot deserts, and from subtropical vegetation to tropical rainforests. While evolving from hunters and gatherers to settled life with agriculture, the interactions of local communities with rich biological diversity available in diverse ecological regions and the landscapes, resulted in domestication of many plant and animal species and evolution of practices for cultivation or rearing and management, for conservation of diverse locally available natural resources, ensuring long-term sustainability and adaption to prevailing environment. These have been further evolved, shaped and maintained by generations of farmers and herders under diverse macro- and micro-environments based on diverse natural resources, use and culture. This resulted in the building of significantly valuable local knowledge and experience about management, conservation and sustainable use of natural resources. Therefore, these ingenious indigenous agricultural heritage systems reflect the microlevel diversity in evolution of agriculture and humankind, the diversity of their knowledge, and their profound relationship with nature.

\section{Prospective Agricultural Heritage Systems in India}

Consequent to size and the wide ecological diversity of the Indian Subcontinent, there are many prospective agricultural systems dispersed over the various agroecological zones, based on the indices commonly used for identification of AHS. However, most need in-depth study for their characterization and evaluation, establishing the unique features and the potential value for notification, documentation, protection and promotion of their science base, as a source of alternative knowledge and genetic material, to meet the challenges of $21^{\text {st }}$ century. They are listed below:

1. Traditional Land Claiming System for Agriculture Use: It is practiced in Ladakh and surrounding cold arid region. It involves channelizing of water from snow-melt streams and rivers to stoned terraced structures (fields) 
during spring. Over years, people disturb the stream or river water with poles or rakes, forcing sediments along with water into stone enclosed terraced fields. Once enough sediment gets deposited, an ecological plant succession starts beginning with the grass stage. Cultivation starts with small grasses and bushy roses using willow trees for fencing. The land is further provided with fertilizers from human and animal wastes, promoting cultivation of staple food crop, such as barley.

2. High Altitude Nomadic Agriculture of Tribes, Like Changpa's: In Rupshu Plateau of southeast Ladakh, following a community approach, high altitude productive pasture lands are maintained in order to provide good grazing lands for yaks, sheep, goats and $d z o$ (a cross between a yak and a local breed of cow); to facilitate livestock rearing and provide fresh dairy products all throughout the year. The community appoints one or two members of the village to take all the animals to higher pastures during the season, where, while the animals graze, the attendants spin wool, make butter, cheese and collect dung for the winter. The pastures close to villages are not grazed during the season and are kept for winter to avoid long distance movement and improve efficiency of pasture use.

3. Terrace Cultivation of Paddy in Valleys, Western Himalaya: It is a system of cultivation of paddy on terraced lands involving ingenious practices, which includes exploitation of natural resources and recycling of crop residue. It is mainly practiced in Himachal Pradesh and Uttarakhand. Rice is the predominant crop of which aromatic rice, such as Basmati, particularly Dehradun Basmati is known world over for its aroma and grain quality. These products are geographically associated with the region. Besides, the system offers rich genotypic variability for diverse traits inherited over times.

4. Crop Rotation and Intercropping Systems: In Uttarakhand (Western Himalaya) farmers have developed diverse crop rotation, and intercropping systems, such as Katil, Upraon and Talaon. Garhwal is known for "Baranaja" (twelve grains) system involving sowing of a mixture of crop seeds. Navadanya, is another popular practice of mixed cropping, involving nine different cereals, pulses, millets, and different kinds of vegetable varieties (intercropped or mixed cropped), ensuring soil health, food and nutritional security. Similarly, tribal communities in Chota Nagpur practice indigenous legume-based mixed cropping and intercropping systems, such as pigeonpea + rice, pigeonpea + black gram, pigeonpea + finger millet, pigeonpea + maize, cowpea + rice, gram + wheat, gram + linseed, and gram + mustard; and crop rotations including rice-gram, rice-lentil, rice-wheat-mungbean, rice-pea, groundnutwheat, maize-wheat and different vegetables. Whereas, in Telangana area of Deccan Plateau tribes and small farmers practice Barhdana system, cultivating 12 or more traditional crops, including cereals such as sorghum, grain legumes such as pigeonpea, oilseeds and other minor crops, following organic farming methods on their small holdings to overcome vagaries of aberrant weather, improve soil fertility and limit pest infestation.

5. Kuls Irrigation System, Western Himalaya: In Jammu and Kashmir, water channel called Kuls carry water from mountains to the fields. Similarly, in Himachal Pradesh, Kuhls have been developed to divert water of natural flowing streams (khuds) for irrigation. A typical community Kuhl services 6 to 30 farmers, irrigating an area of around 20 ha. The Kuhls contains moghas (temporary outlets) to draw out water for the terraced fields. In Hamirpur, Kangra and Mandi, Khatris (structure of size, about 10 feet x 12 feet and six feet deep) are carved into hard rocks and used to provide water for animals, and for washing and drinking. In Uttrakhand, Naula, small wells or ponds collect water by building a stone wall across a stream. This is a typical surface water harvesting system suited to hills.

6. Alpine Semi-nomadic Agropastoral System, Arunachal Pradesh: Monpa are semi-nomadic pastoralists of the alpine terrain of Tawang, Arunachal Pradesh. To feed large stock of yaks and other livestock's, they practice nomadism, 
besides limited horticulture in and around the village. Monpa men take their herds over to long distances in search of pasture. Whereas, the women, children, and the elderly remain in villages, tending the remainder of their livestock, collecting firewood and making handicrafts. For sustainable grazing, they rotate between a multipasture encampment, used in mid- and latewinter, spring, and summer, with an encampment reserved for use in autumn and early winter. This allows them to utilize a series of common grazing lands, while ensuring an ample supply from un-grazed forage reserves for use in autumn and early winter on which the animals subsist through the long winters. Until recently, they followed unique polyandrous system. Since herds are owned by joint family of brothers, and both livestock rearing through nomadism and upbringing of family must be carried out, one herder is replaced by brother after a while, exchanging responsibilities.

7. Apatani's Wet-rice Cultivation, Arunachal Pradesh: It is one of the highly evolved rice cultivation system of the valley, perfected over centuries with effective water and energy use efficiency, and conservation of soil fertility by recycling of crop residues and use of organic wastes and pig dung, achieving maximum output/ input ratio. It is a cooperative system run under the overall supervision of the village headman. Early rice varieties are sown farther away from the village on poor soil, and late varieties on rich soils closer to the village for relay harvest. Depending on conditions, it is combined with pisciculture and finger millet on bunds.

8. Agroforestry System Involving Cardamom and Horticulture Crops, Sikkim: It involves cultivation of large cardamom beneath the forest cover or on marginal land under agroforestry system. Cultivation of broom grass upon terrace risers and Albizia Durazz. trees in large cardamom agroforestry and croplands, contribute to maintaining soil fertility.

9. Rice-fish Cultivation in Rain-Fed Lowland, Brahmaputra Valley: From ancient times, to overcome the excessive flooding during the monsoon and to take the advantage of the situation, the local farmers have developed an indigenous rice-fish farming system, particularly in the lowland floodplains, both in shallow and deep-water rice fields. Naturally occurring fishes and prawns enter the field during the monsoon and grow with rice crop. Fish is harvested as an additional crop.

10. Sericulture System, Assam: The silkworm, Antheraea assamensis Helfer is confined to Brahmaputra Valley of India. It produces the famous Muga silk. The silkworm is raised outdoors primarily on two trees-som (Machilus bombycine King ex Hook.f.) and soalu (Litsaea polyantha Juss.). The Muga silk is known for fine sheen and golden colour and used by the local silk weaving industry. Eri silk, on the other hand, is the product of the domesticated silkworm, Philosamia rinini, which feeds mainly on castor (Ricinus communis L.) leaves. Eri-culture is a household activity practiced mainly for the protein-rich pupae, a food delicacy for the tribe. The word 'Eri' is derived from the Sanskrit name for the castor, Eranada, indicating ancient nature of the practice. Eri silk is spun as it cannot be reeled. Under traditional sericulture, farmers cultivate som, soalu and castor bean for rearing silkworms. This provides livelihood support to the local farmers and weavers.

11. Jhum or Slash-and-burn Cultivation System: Jhum comprises of forestry, hunting, crop cultivation and fishing, based on available resources. It's a traditional community-activity practiced from early days of agriculture round the year, ritually sanctioned and self-contained. It involves clearing an area by slashing and burning of the local vegetation for agriculture. It is practiced in Garo Hills, Khasi Hills, and Jaintia Hills of Meghalaya and in other hilly regions of the India. Garo's have most efficient system with cultivation of crops and animal husbandry components, besides raising of trees, bamboos, etc. In Nagaland, it is practiced by the women of the region to facilitate the conservation of agrobiodiversity with cultivation of multiple (15 to 30 species) crops on the same plot of land after jhum i.e. clearing and called Swidden farming of Angamis. In Koraput hills, 
it is referred to as Podu, involving more minor millets, pulses, etc. in cropping, based on indigenous knowledge. Here, during off season, farmers devote time to storing grains in Dhoosi and Khanike, and collect forest produce for subsistence. In Konkan, it is referred as Rab, and is practiced on higher slopes. The main crops are nachani [Eleusine coracana (L.) Gaertn.], kang [Setaria pallidefusca (Schumach.) Stapf \& C.E. Hubb.], vari (Panicum miliare auct. non Lam.), and some traditional vegetables. Following this practice, farmers burn the piece of land for raising rice nursery. Scientifically, it contributes to partial sterilization of the soil, improves the physical structure and increases the availability of nutrients in the soil. Thereby, helping control of weeds; better germination, healthy seedlings and increasing yield. Though this practice involves wastage of valuable organic matter, which can preferably be used in compost making.

12. Drip Irrigation Using Bamboo Pipes, Meghalaya: It is 200-year-old system used by the tribal farmers of Khasi and Jaintia hills. It involves tapping of stream and spring-water by using bamboo pipes to irrigate plantations of black pepper and other horticulture crops. About 18-20 L of water entering the bamboo pipes per minute gets transported over several hundred meters and finally gets reduced to $20-80$ drops per minute at the site of the plant.

13. Panikehti Rice Cultivation, Nagaland: It is practiced overcoming the problems of diverse altitude, slopy topography and climatic conditions. It involves carrying water from some stream or torrent to terraces and maintenance of about 10 to $15 \mathrm{~cm}$ of water level, facilitated by a stone, kept at the opening of the bund. The excess water runs down to lower terraces through wedge type openings in the bunds, which facilitates efficient use of water and prevents soil erosion.

14. Zabo System, Phek District Nagaland: This is a composite farming system with a combination of forestry, agriculture, livestock, and fisheries. Zabo means impounding of water, evolved to overcome deficient rainfall. Under this system, the first component consists of the top of the hill and areas below, where forests are maintained. This works as the harvested rainwater catchment area. The second component consists a little down collecting water in ponds that are dug according to the size of the catchment and expected quantity of water. These ponds are used as de-siltation tanks. After keeping the water for 2 to 3 days, it is transferred to a larger main tank. The de-siltation ponds are de-silted every year and the material, which contains a good amount of organic matter and nutrients, is spread in the terraced rice fields to improve the soil fertility. The third component consists of livestock enclosures of bamboo a little below the main water storage tank. Generally, a few families keep their animals together in one enclosure. The fourth component is the rice fields, which, at the time of irrigation, get water from the main tank. As water passes through the livestock enclosures, it carries dung and urine mix of the animals to the fields along with the flow, providing much needed fertilizers/ nutrition to the soil.

15. Alder (Alnus nepalensis D.Don.) Agroforestry System, Nagaland: It is an agroforestry system involving planting of the alder trees to enhance the soil fertility with crops such as maize, job's tears, millet, potato, chili, pumpkin, barley, etc. Alder is a non-leguminous tree that fixes atmospheric nitrogen through nodules on the roots. In addition, the litter of the trees add phosphorus, potassium, calcium, and other nutrients to the soil along with biomass. The timber of Alder is used for furniture and fuelwood.

16. Water Conservation and Irrigation Systems (Tankas, Vav, Khadins), western arid India: To overcome water constraints of the desert/ arid conditions, local communities have developed suitable practices to support life and agriculture, such as tankas- underground tanks in houses of Bikaner and Jodhpur; step-wellscalled 'Baoli' or 'Bavadi' in Rajasthan and 'Vav' or 'Vavadi' in Gujarat, used both for drinking and irrigation purposes; and khadins (dhora)an ingenious construction designed to harvest surface runoff water for agriculture. It is 
practiced since 15 th century to facilitate conservation and efficient use of water. Khadin's main feature is earthen embankment built across the lower hill slopes lying below gravelly uplands.

17. Arid Agroforestry System, Involving Khejri Prosopis cineraria (L.) Druce] and Marwar teak (Tecomella undulata (Sm.) Seem.), arid Rajasthan: Recognizing the importance of trees in mitigating dry conditions, the local people have identified indigenous multipurpose trees, such as khejri and Marwar teak for cultivation under agroforestry. They fulfil the basic need of food, fodder, feed, fuel, shelter and timber, besides supporting agroecosystem and crop. Khejri is mentioned in Indian Vedic scriptures, reflecting ancient nature of the system.

18. Nomadic Livestock Rearing and Breeding, Rajasthan and Gujarat: Tribes like the Raikas live life of nomadic herds men. Responding to the vagaries of nature, they have developed resilient indigenous breeds, and maintained them within restricted social groups. Their memorization of the pedigree lineage for 7 to 8 generations is worth appreciation, and their role as guardians of livestock diversity, has led to recognition of their system under the Globally Important Agricultural Heritage Systems (http:/ /www.fao.org/sd/giahs/other_india2.asp).

19. Pat Rainwater Harvesting System, Jhabua, Madhya Pradesh: Devised according to the peculiarities of the terrain to divert water from swift-flowing hill streams into irrigation channels called pats. The diversion bunds across the stream are made by piling up stones and then lining them with teak leaves and mud to make them leak-proof. The pat channel negotiates small nullahs that join the stream off and on and sheer cliffs before reaching the fields. These sections invariably get washed away during the monsoons. Stone aqueducts are built to span the intervening nullahs. The villagers irrigate their fields by turns. The channel requires constant maintenance and it is the duty of the family irrigating the fields on a day to take care of the pat on that day.
20. Durum Wheat Cultivation System, Malwa Plateau, Madhya Pradesh: The unique climatic conditions of the Malwa Plateau were discovered to support production of non-mottled, lustrous and bold grains of durum wheat [Triticum turgidum L. var. durum (Desf.) Yan ex P.C. Kuo: syn. T. turgidum L. Sub sp. durum (Desf.) Husn.; T. durum Desf.] in ancient times. The traditional durum wheat from the region is considered premium wheat with high protein content, which is largely used in making high-quality bakery products.

21. Dryland Agriculture, Semi-Nomadic Animal Husbandry and Dairy Farming System, Kathiawar peninsula: Based on local resources and exotic introduce adapted to semiarid conditions, dryland crop farming, animal husbandry, and dairy farming is developed by the farmers of peninsula. Crop farming is dominated by cash crops (cotton, groundnut). Animal husbandry and dairy farming is based on indigenous breeds, such as Gir and Kankrej cattle, geographically associated with Gir Forest, and southeast Rann of Kutch and adjoining areas of Rajasthan respectively, and multiple-utility animal like Kathiawari horse. The livestock census of 1997 revealed 21 million livestock in Gujarat producing highest livestock products. The indigenous nomadic breeders, such as Rabaris, Maldharis, Kuchchhis, etc. are credited with improvement of livestock, and preservation of good strains.

22. Chandeli-pond's System for Surface-Water Conservation and Irrigation, Bundelkhand: Several centuries ago, with the support of rulers like the Chandelas and the Bundelas, the local people tapped water of many streams exploiting the sloping topography and by building embankment for harvesting and storing water in structures such as lakes and surfacereservoirs in the region. Consequently, each village in the region has ponds/tanks to meet the water needs of the inhabitants. The Chandelas created number of ponds now known as Chandeli-ponds for irrigation and drinking water in Chhatarpur, Tikamgarh, etc. of Bundelkhand region. Many are still in use. 
23. Zaid, $3^{\text {rd }}$ Crop Cultivation System on Residual Moisture of River Beds, Bundelkhand: The 'zaid' practice involves cultivation of watermelon, musk melons, and vegetables on raised beds of the dried river bed of Yamuna in Bundelkhand region during summers. It is developed to harness third crop (summer) in a year. This practice has now spread over Gangetic plains.

24. Gwari Pasturelands and Annapratha, the Open/stray Grazing System, Bundelkhand: Cattle from black soil areas of the plains are sent to pasturelands in plateau and hilly areas (known as gwaris) during the monsoon, under the supervision of charwahas who build temporary shelters for themselves and the animals. Animals from several neighbouring villages are reared in this manner for a period of three to four months (www.bundelkhandinfo. org). In addition, open grazing is the norm, including stray grazing, a practice known as Annapratha - where animals are left to roam around and find food for themselves.

25. Beushining Rice Cultivation System, Upper Gangetic Plains: It is a traditional practice involving ploughing after 25-30 days of sowing, at $50 \mathrm{~cm}$ distance in the rainfed and upland agroecosystems. This facilitates stable rice yield under low input management and uncertain climatic conditions, through effective weed control, optimum plant stand, stimulated root growth and enhanced tillering.

26. System of Crop Residue (Wheat Straw, Pulse Peel, Oilcake) use as Fodder, Gangetic Plains: In upper and middle Gangetic Plains, a unique practice evolved, facilitating the effective utilization of productive crop residue as fodder sustaining livestock rearing (for dairy and agriculture power). Wheat crop residue has been the basis, which is more palatable and has been in great demand. It is intensively collected, stored and used as basal animal feed, because of nutritive value and easy storage in rural storehouses (khatti) made of pigeonpea or other herbal stalks. It ensures round the year availability of feed. Cereal straw is supplemented with other crop residue/by- products, such as pulse peels, oilcake, etc. Surpluses are traded into towns to facilitate urban dairy farming and gain additional income. Revitalization of this system in India can be an alternative to overcome the problem of crop residue burning, causing environmental pollution in today's rice-wheat rotation system.

27. Boro Rice Cultivation System: Boro is a Bengali word derived from the Sanskrit Borob, which means a special type of rice cultivation on residual or stored water, in low-lying areas. This is a special type of rice cultivation in waterlogged, low-lying or medium lands, with irrigation during November to May or on residual or stored water in low-lying areas, after the harvest of kharif rice. It is mainly confined to middle and lower Gangetic Plains. Its association with Sanskrit technical term reflects, practice of this system from ancient times.

28. Aquatic makhana (gorgon nut) Cultivation System, Bihar: The Bihar region of Middle Gangetic Plains has developed some unique agronomic practices for cultivation of makhana (Euryale ferox Salisb.), an aquatic weed that grows in the shallow water bodies of northern Bihar. Bihar is the largest producer of makhana.

29. Pisciculture: Fish Culture in Ponds and Water-Logged Paddy Fields, Middle Gangetic Plains: Fishery is an age-old component of traditional agriculture in India. In rural areas, it is generally practiced in waterlogged paddy fields and water bodies (ponds) around villages in Middle Gangetic Plains.

30. Pynes and Aahar Irrigation System, Middle Gangetic Plains: During Magadha period traditional system of irrigation, involved fetching of water from rivers to fields through pynes (small nullahs) and storing it in a pond-like structure called aahar (catchment basin, embanked on three sides, with the 'fourth' side being the natural gradient of the land itself). Starting out from the river, pynes meander through fields to end up in an ahar. Most pynes flowed within $10 \mathrm{~km}$ of a river and their length was not more than $20 \mathrm{~km}$. Pynes were used to water fields on both sides, and aahar 
was used to supply water to drought-hit lands. Between them was a perfect 'water-tight' system to ensure that irrigation facilities cover all the sown fields. Aahar beds were also used to grow a rabi (winter) crop after draining out the excess water that remained after kharif (rainy season) cultivation.

31. Cultivation of Water-Loving Jute and Allied Fibres, Gangetic Delta Region: Jute is one of the major crops of the Gangetic Delta, cultivated as an additional/alternate crop, particularly in the areas prone to flooding. More than $85 \%$ of the world production of jute comes from the Gangetic Delta. The soil of the Gangetic Delta creates a great platform for growing jute. Jute cultivation can be classified into three areas, Brahmaputra Alluvium, Ganga Alluvium, Teesta Silt. Other allied fibre crops grown are sun hemp.

32. Paira Cropping System, Chota Nagpur Plateau: It is practice of no-tillage, involving relay sowing by broadcast in standing maturing rice crop of lowland, before its harvest. This practice saves time; money (to be spent on land preparation etc.) and utilizes residual moisture and fertility.

33. Sericulture-Rearing/Breeding of Moth/ Silkworm of Tasar silk, Chota Nagpur: Tasar culture is a way of life among the tribes and forest dwellers of Chota Nagpur. The leaves of trees such as Terminalia tomentosa Wight $\&$ Arn. and T. arjuna (Roxb.) Wight \& Arn. are used as hosts, providing feed for rearing and breeding of the moth. Moth produces cocoon from which tasar yarn is reeled for the sericulture industry.

34. Rearing of lakh or Lac Insect to Support Lac Industry, Chota Nagpur: Leaves of Acacia and Ficus spp. are used for rearing of lakh or lac insects Laccifer lacca Kerr. for the lac industry. The sticky, resinous secretion of the tiny lac insect's deposits on the twigs and young branches of several varieties of soapberry, Acacia trees and the sacred fig (Ficus religiosa L.) in forests. This is commercially exploited to produce lakh. The Chota Nagpur region contributes $41 \%$ of the total lakh production of the country.

35. Rice Cultivation of Bastar and Adjacent Areas (A Regional Centre of Rice Diversity): The terrestrial heterogeneity creating diversity of topography with toposequences of soils, ecology, agro-ecoclimate and hydrology, coupled with variation in cultural heritage of the inhabitants, effecting differential selection pressures, has generated rich genetic diversity. This has resulted in the evolution of significant levels of variability in the local rice germplasm (aromatic and nonaromatic) with associated indigenous knowledge. Dr Richharia collected 18,541 rice varieties from the region (Singh, 2013).

36. Exploiting Ecological (Altitude) and Plant Diversity for Domestication and Generating Diversity, Koraput: The topographic heterogeneity of the Koraput region has produced a wide diversity in the ecosystems, perpetuating rich floristic diversity represented by around 582 to 947 plant species with $4 \%$ endemism (Misra et al., 2009; Mohapatra et al., 2009), including edible and economically important plant species. It has resulted in domestication of few species such as Oryza, Cajanus, etc. Responding to the topographical and ecological diversity, the rural and tribal communities of the Jeypore-Koraput tract has evolved diverse traditional cultivation practices of domesticates, particularly rice. Rice is cultivated under wide range of agroecosystems, including uplands, lowlands, and irrigated as well as rain-fed landscapes, resulting in maintenance and conservation of notable varietal diversity based on traditional knowledge and innovative practices, to ensure food security and continuing adaptation to changing environmental conditions. The system(s) conserve nearly 160 locally adapted rice cultivars, based on the indigenous farming, recognized widely, earning the Award of Equator Prize instituted by the UNDP in 2002 (https://www.equatorinitiative.org/wp-content/ uploads/2017/.../case_1348261060.pdf). The rice researchers consider the Jeypore-Koraput tract as the secondary (independent) centre of origin of rice, and genetic diversity. This has resulted in the designation of the Koraput region 
as one of the Globally Important Agricultural Heritage Systems (GIAHS)(www.fao.org/giahs/ giahsaroundtheworld/en/).

37. Myda and Jhola Rice Cultivation Systems, Koraput: Responding to the topographical and ecological diversity of the Koraput region, the early settlers of the region belonging to AustricAsian races evolved systems, like myda cultivation, practiced by Gadabas, involved with growing of two varieties of rice together in the same field during kharif season in plateau. Whereas, Saoras evolved the Jhola cultivation system in highland landscapes with terraces prepared with support of boulder walls. The terraces on uplands hillside sustained by rough stone packed revetments are wonderful eyecatching scenes, reflecting ancient nature of the system.

38. Semi-nomadic Pastoral Farming and Dryland Agriculture System, South-Central Eastern Ghats: The dry ecological conditions and lack of perennial sources of water with rich livestock diversity and land resources like savannah grassland and thorny thickets for feeding animal, has resulted in evolution of seminomadic pastoral farming system. Its practice from ancient times is indicated by archaeological ash mounds of cattle dung discovered at Neolithic sites in South India reflecting the presence of pastoralist camps (Allchin, 1963). The animal and plant remain found at the excavated sites suggest the dominant role of domesticated cattle, with supporting rainfed agriculture of crops like millets, beans, common pea, horse gram, black gram, and rice, particularly in Rayalaseema and parts of Nellore and Prakasam, Bellary, Richur and Kolar. This has resulted in the evolution of many indigenous hardy breeds of cattle (Ongole) and sheep; and drought-resistant cultigens in millets and pulses.

39. Cheruvus (reservoir) System, Chittoor and Kadapa: In Chittoor and Kadapa districts of South-Central Eastern Ghats, to overcome the scarcity of water due to low rainfall, absence of perennial rivers, and unpredictable weather, a network of water tanks and reservoirs (cheruvus) were developed to store runoff water. Cheruvus are embankments that are fitted with thoomu (sluices), an artificial passage for water fitted with a valve or gate for stopping/ regulating the flow; alugu or marva or kalju (flood weir)- a barrier across the passage is designed to alter the flow; and kalava (canal) are channel for water discharge.

40. Grand Anicuts System, Cauvery Basin: It involves building of stone embankment named Kallanai dams, with network of irrigation canals (Vira Pandyan-Kal) and water reservoirs (Vallabha Pereri) for extended irrigation and supply of drinking water. The Cauvery River is interrupted by twelve dams ('anicuts')- Grand Anicut, and the water is diverted through artificial channels for irrigation and for drinking. The Grand Anicut is originally believed to have been built in the mid to late Chola times and was later rebuilt by the British.

41. Korangadu Grazing System, Tamil Nadu: Korangad $u$ is a traditional grazing grassland in the semi-arid tracts of the districts of Erode, Karur, and Dindigul, Tamil Nadu. It consists of paddocks (small enclosed fields) having combination of grasses, legumes and trees for grazing. They are fenced with live thorny shrubs of mullukiluvai [Commiphora berryi (Arn.) Engl.], a thorny drought-resistant shrub. They are used as sustainable support for livestock rearing and as breeding tract, called Kangayam of cattle, which supply good quality plough and draft bullocks, local buffaloes and native breeds of sheep (Mayilambadi breed) and goats. This unique system displays indigenous knowledge regarding the management and conservation of unique animal breeds, their upkeep, rearing and breeding along with conservation of grasslands.

42. Catamaran Coastal Fishing System, Coastal Tamil Nadu: It is a sustainable ecofriendly traditional fishing system. The Catamaran is a type of multihulled boat or ship consisting of two hulls (vakas), joined by some structure, the most basic being a frame (akas). It has evolved into a light watercraft called Kattumaram in Tamil. The word kattu means 'tie', and maram is the 'wood tree', thus, Kattumaran simply means 'tying two trees 
together'. It was invented by the Parava's, an ancient coastal aristocratic fishing community of southern India, Tamil Nadu.

43. Kohli tanks, Bhanadara (check dams) and Phad system, Tapti River Basin: In semiarid tropic areas of north-western Maharashtra, locals have developed traditional water harvesting systems. The kohli tank system, built in Bhandara district, comprises several water tanks of different sizes used for irrigation of sugarcane and rice, often with the provision of bringing water to village farms from river. The check dams called Bhanadaras are built across rivers, raising the water level and forcing it to flow into the channels. They are also used to impound water from reservoirs. Villagers or individuals building such structures receive rentfree land in return. The phad is an improvised community-managed irrigation system. It starts with a bhanadara and is branched out into kalvas (canals) with a discharge capacity of about 450 litres per second. The lengths of these kalvas vary from 2 to $12 \mathrm{~km}$. From kalvas, charis (distributaries) are built for carrying/ feeding water to different areas of the phad. Phad sarangs (field channels) channelize the water to individual fields. The sandams (escapes) are built along these structures to drain away the excess water.

44. Daarche Paani System, Konkan: Recognizing water scarcity during summer and to ensure water availability throughout the year, community-managed water harvesting systems have been developed by locals in Konkan region. Daarche Paani involves man-made tanks, channels, and falls on small flat plateau called 'Sadaa' supplying water to villages and for irrigation of plantations. Daarche Paani consists of seven tanks, each built in stone at different levels. The first tank receives continuous freshwater from an underground spring and is called Devache Taake ('Tank of the Gods'). This overflows through a channel to a drinking water tank, from where the women collect water. Washing and bathing near these tanks is prohibited. It is cleaned daily by the first and the last user. Then, water flows to a bigger tank for the cattle with gently sloping margins. Margins of tanks are interesting to see, allowing small animals as well as birds to use, without the perennial danger of a thirsty one falling in and drowning. Next in the hierarchy are the tanks for cleaning and bathing, which have specially built stone platforms. These tanks converge into a channel, which flows down to irrigate indigenous plantations (areca nut and pepper) in downstream. Finally, small spring eventually joins the river and meets the Vashishthi estuary (Dandekar, 2010).

45. Ulkatni and Awatni Rice Cultivation System, Konkan: Ulkatni and Awatni are two local practices followed in the Khar (salty) lands of Thane and Raigad districts of Maharashtra. In Ulkatni, the clods are turned upside down with the help of a crowbar in the months of AprilMay. Whereas, Awatni is the practice of putting the rice seedlings in the field along with the mud ball from the seedbed (transplantation) after ploughing. It was observed that both the methods of preparatory tillage were effective. Hence, instead of Ulkatni, which was done manually, ploughing could be done after the harvest of kharif rice in reclaimed Khar lands. Awatni was significantly superior to the regular practice of transplanting, provided the plant population is maintained. Surface (superficial) planting in Awatni avoids contact of the tender seedlings with the salty portion of the soil, avoiding seedling mortality. This practice has generated large genetic diversity.

46. Mixed Poly-Cropping System, Northern Western Ghats: Warli community living in the Warli Hills of Maharashtra follow complex multiple mixed cropping of annuals and perennial crops, making optimum use of the available resources. Based on multiline concept, it includes cultivation of multiple varieties of a crop fulfilling different requirements and maturity duration, providing insurance against crop failures. Further exploiting tropical climate with high rainfall, it also includes cropping of horticultural crops facilitating effective and efficient land use, with more crop per unit area and per drop, providing greater income. Several mixed cropping systems have evolved in the region, including both rainfed and irrigated cereals, 
pulses, vegetables, fruit and plantation crops, such as spices.

\section{Pokkali' and 'Kaipad', Rice Cultivation} Systems, Malabar Region: Under these systems, the excess water caused by excessive rains and regular action of sea waves and shore currents in the coastal areas and in the areas below sea level, has been harmoniously and profitably managed by the local populations with ingenuity. It includes, practice of rice cultivation in waterlogged areas of southern coastal Kerala (Alappuzha), called 'Pokkali'. It is a unique cultivation system of salinity-tolerant rice varieties cultivated in an organic way in the waterlogged coastal regions. It has been further improved with integrated rice-shrimp/prawn farming. One rice crop followed by shrimp/ prawn capture provides a substantial subsidiary income to the farmer (Jayan and Sathyanathan, 2010). This system is also practiced in Thrissur and Ernakulam districts.

In Kannur district of North Kerala, a similar system called 'Kaipad' is practiced with the rich biodiversity of flora and fauna, organically rich soil, mangroves, and migratory birds. It differs from 'Pokkali' in the way it is carried out, which is purely natural way relying on the monsoon and the sea tides. Besides, it has its own salinity-tolerant landraces of rice and highyielding rice varieties (Vanaja, 2013). Kaipad is also practiced in Kasaragod and Kozhikode. These systems together have been notified by FAO as GIAHS, the Kuttanad rice cultivation below sea level (www.fao.org/giahs/ giahsaroundtheworld/designated-sites/.../ kuttanad...system/en/).

48. Homestead Polyculture Farming Systems, Malabar Region: In hilly and mid land zones of Southern Western Ghats, the system of homestead farming is practiced, growing of a wide variety of crops. Farmers choose their crop combinations and livestock or fish farming as per the prevailing conditions. Several intercrops are raised, resulting in a multi-story cropping pattern with canopy stratification. Perennial tree crops such as coconut, areca nut, jack fruit, mango, cashew, tamarind, and forest tree species occupy the upper layer; pepper, clove, nutmeg, cinnamon, cocoa, etc., occupy the second layer; banana, cassava, yam, cocoyam, etc., occupy the third layer; and ginger, turmeric, pineapple, vegetables, grain legumes, and guinea grass occupy the ground layer. This approach nearly attains the tropical rainforest structure with wide species diversity, which is its science base and might have stimulated indigenous farmers for adoption involving economic plant species. It often includes livestock.

In addition, there are heritage systems related with economic exploitation and management/ conservation of biological diversity while supporting agriculture. They either provide further opportunities for expansion of agriculture with domestication/ cultivation of more economically important plants and rearing of animal species or indirectly support agriculture with interactions of natural resources. For example, the health/medicinal systems (SowaRigpa or Amchi, Ayurveda, Sidha, etc.) based on medicinal/nutritional properties of plants, mostly exploited from the nature; sacred groves [Meghalaya, Deogudi of Bastar; Deva Vanas, North-western Deccan Plateau; Devarai, Devarakavu, Kan with Kalkai (deity), Konkan; and Kavu or Serpa Kavu, southern Western Ghats] facilitating conservation of natural resources (water) and species diversity, particularly wild relatives of crop species. Most of these Agricultural Heritage Systems (AHS) have been briefly described by Singh (2015), as components of the various National Agricultural Biodiversity Heritage Sites. The Table 1 lists these AHS, providing a bird's eye-view of their location, significance; and scientific principles involved.

\section{FAO Initiative}

To safeguard and support the world's important AHS, FAO initiated a project for identification and dynamic conservation of Globally Important Agricultural Heritage Systems (GIAHS) in 2002 (GIAHS, 2002). This GIAHS initiative, now referred as GIAHS Program, under FAO promotes public understanding and awareness development about AHS, and their national and international recognition. To date FAO has identified 36 sites in 15 countries after scientific evaluation. 
Table 1: Prospective Indian agricultural heritage systems of significance

\begin{tabular}{|c|c|c|c|}
\hline S.No. & $\begin{array}{l}\text { Prospective agricultural } \\
\text { heritage systems }\end{array}$ & Science base, salient features and potential value & Area of practice \\
\hline 1. & $\begin{array}{l}\text { Traditional land claiming } \\
\text { system for agriculture }\end{array}$ & $\begin{array}{l}\text { Ecological succession used by channelizing sedimented } \\
\text { water from river/streams into freshly stone built } \\
\text { terraced field, followed by natural plant succession } \\
\text { and cultivation }\end{array}$ & $\begin{array}{l}\text { Cold arid region of Leh to Nubra } \\
\text { valley and Gilgit }\end{array}$ \\
\hline 2. & $\begin{array}{l}\text { High altitude nomadic } \\
\text { agriculture of tribes }\end{array}$ & $\begin{array}{l}\text { High altitude grazing by turn leaving close pastures for } \\
\text { winter (community practice) }\end{array}$ & $\begin{array}{l}\text { Upper limits of western } \\
\text { Himalayas, tribe Changpa's }\end{array}$ \\
\hline 3 & $\begin{array}{l}\text { Terrace cultivation of paddy } \\
\text { in valleys }\end{array}$ & $\begin{array}{l}\text { Rice (including aromatic) cultivation on terraced lands, } \\
\text { recycling crop residue for sustainability of soil fertility }\end{array}$ & $\begin{array}{l}\text { Himachal Pradesh and } \\
\text { Uttarakhand, Western Himalaya }\end{array}$ \\
\hline 4 & $\begin{array}{l}\text { Crop rotation and } \\
\text { intercropping system }\end{array}$ & $\begin{array}{l}\text { Crop rotation and intercropping harnessing benefit of } \\
\text { interactions \& residue in diverse micro ecologies- } \\
\text { Baranaja, Navadanya }\end{array}$ & Uttarakhand, Western Himalaya \\
\hline 5 & Kuls irrigation system & $\begin{array}{l}\text { Surface harvesting of water by channelizing natural } \\
\text { flowing stream from mountains to field }\end{array}$ & $\begin{array}{l}\text { Himachal Pradesh, and } \\
\text { Uttarakhand, Western Himalaya }\end{array}$ \\
\hline 6 & $\begin{array}{l}\text { Alpine semi-nomadic } \\
\text { agro-pastoral system }\end{array}$ & $\begin{array}{l}\text { Distant grazing by taking herds to long distance pastures } \\
\text { by turn, leaving children, women and elderly back, } \\
\text { tending remaining livestock. A family practices }\end{array}$ & $\begin{array}{l}\text { Tawang, Arunachal Pradesh, } \\
\text { Eastern Himalaya, tribe- } \\
\text { Monpa pastoralists }\end{array}$ \\
\hline 7 & Apatani's wet-rice cultivation & $\begin{array}{l}\text { Based on effective water and energy use and conservation } \\
\text { of soil fertility by recycling of crop residues, organic } \\
\text { wastes, dung, achieving maximum output/input ratio }\end{array}$ & $\begin{array}{l}\text { Arunachal Pradesh, Eastern } \\
\text { Himalayas, tribe- Apatani }\end{array}$ \\
\hline 8 & $\begin{array}{l}\text { Agroforestry system } \\
\text { involving cardamom and }\end{array}$ & $\begin{array}{l}\text { Large cardamom or horticultural crops plantation beneath } \\
\text { forest cover and on marginal lands }\end{array}$ & Sikkim \\
\hline
\end{tabular}

Taking advantage of excessive flooding during monsoon in lowland floodplains, cultivating rice and fish

Exploiting local host plants to rear silkworm, Antheraea assamensis and Philosamia rinini producing Muga and Eri silk respectively

11 Jhum or slash-and-burn cultivation system

12 Drip irrigation using bamboo pipes

13 Panikehti Rice Cultivation

14 Zabo system of composite farming system

$15 \quad$ Alder (Alnus nepalensis) agroforestry system

16 Water conservation and irrigation systems with Tankas, Vav, Khadins

17 Arid agroforestry system

18 Nomadic livestock rearing and breeding system
Primitive agriculture practiced on plots cleared after slashing and burning the vegetation and cultivating economic plants

Using bamboo pipes, trapping stream and spring-water to irrigate plantations

Carrying of water from stream or torrent to terraces of rice fields in controlled manner, restricting soil erosion

Impounding of water at various levels, to practice composite community farming with a combination of forestry, livestock, irrigating rice fields and fisheries

Planting of non-leguminous alder trees to enhance the soil fertility with nitrogen and other nutrients

Use of tankas (underground tanks), vav (step-wells) and khadins (impounded runoff water) for drinking and irrigation

Field planting of multipurpose trees, Khejri (Prosopis cineraria) and Marwar teak (Tecomella undulata)

Development of resilient indigenous breeds of cattle, sheep, camel, etc., and their maintenance within restricted social groups of nomadic tribes
Brahmaputra Valley

Assam Hills

Meghalaya, Nagaland tribeAngami, Koraput and Konkan

Khasi, Jaintia and Garo Hills, tribe-Austro-Asiatic

District Phek, Nagaland, Naga tribes

District Phek, Nagaland, Naga tribes

Nagaland, Naga tribes

Western arid zone (Bikaner, Jodhpur) and Gujarat; Paliwal community

Western arid and Central Rajasthan

Western arid and semi-arid zone of Rajasthan and Gujarat, tribes, Raikal Rabaris, Maldharis 
S.No. Prospective agricultural $\quad$ Science base, salient features and potential value $\quad$ Area of practice heritage systems

19 Pat rainwater harvesting system

20 Durum wheat cultivation system

21 Dryland agriculture, seminomadic animal husbandry, and dairy farming system

22 Chandeli-ponds for surfacewater conservation and irrigation

23 'Zaid" $3^{\text {rd }}$ crop cultivation system on residual moisture of river beds

24 Gwari pasturelands and Annapratha (open/stray grazing) system

25 Beushining rice cultivation system

26 System of crop residue use as fodder

27 Boro rice cultivation

28 Aquatic makhana (gorgon nut) cultivation

29 Pisciculture-fish culture in ponds

$30 \quad$ Pynes and aahar irrigation system

$31 \quad$ Cultivation of water-loving Jute and allied fibres

32 Paira cropping system

33 Sericulture-for Tasar silk production

34 Rearing of lakh or lac insects for the lac industry

Rice cultivation of Bastar and adjacent areas
Diverting water from swift-flowing hill streams into fields via irrigation channels, pats, nullahs.

A community effort

Exploiting unique climatic conditions to support production of non-mottled, lustrous and bold grain of durum wheat

Dryland farming with cash crops suited to semi-arid conditions, and animal husbandry exploiting rich diversity of local breeds of nomadic breeders, facilitating dairy industry

Exploiting sloping topography to build embankment in watershed areas for trapping of water, in structures like lakes or surface-reservoirs

Taking advantages of residual water of river beds, raising of $3^{\text {rd }}$ crop of melons and vegetables

Grazing on pasturelands and open/stray grazing supporting livestock

Ploughing $50 \mathrm{~cm}$ apart after 25-30 days of sowing to improve crop-growth due to improved soil aeration and weeding

Use of crops residue (wheat straw, pulse peel, oilcake), as fodder, ensuring round the year feed for livestock and additional income

Cultivation of rice in waterlogged, low-lying or medium lands with or without irrigation

Cultivation of makhana (Euryale ferox), an aquatic weed in the shallow water bodies

Fish culture, primarily in ponds around villages, and water-logged paddy fields

Fetching water from river, stored in ponds (aahar) and then taken to field by nullahs (pynes). Aahar beds are used for rabi crop

Cultivation of water loving to jute $\&$ allied fibres in three delta areas of Bengal

No tillage cultivation by relay cropping through broadcast method in standing crop of lowland rice before its harvest

Rearing and breeding of moth/silkworm on Terminalia arjuna (Arjuna) and T. tomentosa (Asan), the host plants to produces cocoon

Laccifer lacca (Kerr) is reared on the leaves of Acacia and Ficus spp., which deposits sticky, resinous secretion of the insect

Cultivation of diverse rice varieties under terrestrial heterogeneity and application of differential selection pressures of local communities

36 Exploiting ecological (altitude), Cultivation of rice in heterogenic altitude and wide range and plant diversity for domestication and creation of genetic diversity of agroecosystems, resulting in generation maintenance/ conservation of varietal diversity
District Jhabua, Malwa

Plateau, Madhya Pradesh

Malwa Plateau, Madhya Pradesh

Semi-arid region of Kathiawar peninsula, animal breeding tribe, Rabaris Maldharis

Semi-arid districts, Chhatarpur, Tikamgarh, Bundelkhand; communities Chandels, Bundelas

Along Yamuna River in

Bundelkhand

Plateau and hilly areas of Bundelkhand

Rainfed and upland ecosystems of Upper Gangetic Plains

Upper and Middle Gangetic

Plains

Primarily in Middle and Lower Gangetic Plains

Ponds of Bihar region of Middle Gangetic Plains

Middle and Lower Gangetic Plain

Middle Gangetic Plains

Bengal delta region

Tribal communities of Chota Nagpur plateau

Tribal communities of Chota Nagpur

Tribal communities of Chota Nagpur

Chhattisgarh, local tribes and communities

Jeypore tract of Koraput bordering Bastar- AustroAsiatic tribes

\author{
Asiatic tribes
}


S.No. Prospective agricultural heritage systems

$37 \quad$ Myda and Jhola rice cultivation systems

Semi-nomadic pastoral farming and dryland agriculture

Cheruvus (reservoir) system

Grand Anicuts (dams) system or river management

$41 \quad$ Korangadu grazing system

$42 \quad$ Catamaran coastal fishing system

Ulkatni and Awatni rice cultivation system

Pokkali' and 'kaipad', rice cultivation systems farming systems

Mixed poly-cropping system
Science base, salient features and potential value

Using multiline concept, cultivation of two varieties

of rice together in kharif on plateau (Gadabas), and terrace (Jhola) cultivation on hill sides (Saoras)

Interacting with dry condition, land, phyto-resources and livestock diversity, domesticated and bred hardy breeds of cattle (Ongole), sheep, etc, and droughtresistant supportive millets and pulses

Overcoming water scarcity by storing runoff water in a network of water tanks and reservoirs built by embankments

Building of stone embanked Kallanai dams and a network of irrigation canals over course of river for extended irrigation and drinking water

Enclosing fields having combination of grasses, legumes and trees for grazing and breeding with fencing of thorny shrubs

Use of a multihulled boat or ship (Catamaran) for sustainable eco-friendly fishing. This watercraft is called Kattumaram in Tamil

Community-managed irrigation systems with tanks, bhanadaras (check dams) built across rivers, raising water level and taking it to fields by canals (kalvas)

Community-managed water harvesting systems with tanks, channels, and falls on small flat plateau called 'Sadaa', supplying water to villages and fields for irrigation

Practice followed in salty soil, where the clods are turned upside down before sowing in Ulkatni, while in Awatni after ploughing, rice seedlings are put along with the mud in the field to avoid contact with salt contents

Practice of multiple mixed cropping, including multiline and diverse rainfed and irrigated fruit and plantation crops with cereals, pulses, vegetable, spices, etc.

Cultivation of salinity-tolerant rice varieties below sea level or under excessive flood waters caused by sea waves, through network of backwaters or eco-friendly practices

Multi-storeyed intercropping like tropical rainforests with a range of crops (trees to basal herbs) in backyard gardens, often combined with livestock
Area of practice

Koraput, tribes- Gadabas, Saoras

Rayalaseema, parts of Nellore, Prakasam, Bellary, Raichur and Kolar of South-Central Region of Eastern Ghats

Chittoor and Kadapa district of South-Central Eastern Ghats

Course of Cauvery river basin

Semi-arid areas of Tamil Nadu

Coastal areas of Tamil Nadu

Bhandara district and Tapti River Basin

Konkan Region

Thane and Raigad districts of Konkan Maharashtra

Warli tribe of Warli Hills

Maharashtra, northern

Western Ghats

Southern coast of Kuttanad, Alappuzha (Pokkali); North Kerala-Kasaragod, Kozhikode and Kannur (kaipad)

Malabar region of southern Western Ghats
Recognizing the value of these systems in conservation of renewable natural resources and sustainable agriculture in an environment friendly manner, and for protection of indigenous technical knowledge(ITK), this program envisages looking after and protection of these systems to safeguard the social, cultural, economic and environmental goods and services, which these systems have been providing to farmers families, smallholders, indigenous peoples and local communities. The program fosters an integrated approach, combining conservation of natural resources, sustainable agriculture and rural development. It can facilitate the potential replication or improvisation of agricultural systems, in other parts of the world with similar ecologies and landscapes. The present overview attempts to identify such 
systems spread over the different agroecological zones of India (Sehgal et al., 1992), bringing them into scientific domain for further investigation, leading to their characterization, evaluation, and assessment of potential value from scientific knowledge and practical application point of view, particularly in management of natural resources and sustain/improve agriculture in difficult/extreme ecologies of the world, taking advantage of FAO initiative.

FAO initiative has been providing systematic support for protection through preservation and adaptive management of such AHS at-

- Global level, through their identification and due recognition

- Encouraging the national programs to create policies for support and safe guard the significantly important AHS

- Learning lessons by working directly with custodian communities on accrued benefits and on the management and dynamics of conservation of their agricultural heritage systems and sharing them with others, based on fair and equitable sharing of commercial benefits accrued, if any.

\section{Possible Criteria for Identification of Important Agricultural Heritage Systems}

To strengthen FAO efforts, it is suggested to adopt a participatory methodology for identification of AHS involving both the farmers and agricultural scientists representing concerned disciplines, as the scientific perceptions may vary. Following general indices can be used for identification of the prospective agricultural heritage system:

- The system should be rich in agricultural biodiversity, contributing to food and nutritional security and/or livelihood support to farming communities.

- It should be associated with biodiversity and ecosystem functions, with rich and unique agricultural biodiversity and genetic resources (species, landraces, farmers varieties, breeds and strain, etc.) as well as other biodiversity components supporting agroecosystems, such as wild relatives, pollinators and the wild life associated with agricultural and landscape (using them for economic benefits and/or overcoming constraints).

- It should be preserving valuable knowledge about local natural resources, indigenous technologies and management systems of natural resources, and the landscape to which it is habitat to.

- Should be rich in cultural and social values, through cosmovision, ethics and ideals (laws) and agricultural practices associated with environment, and agricultural calendar/cycle, festivals, rituals, and system of information/ knowledge exchange.

- Landscape and other features resulting from human intervention/management, facilitating land and water management (e.g. Cauvery basin), contributing to landscape and overall development.

- Finally, the degree of dependence of the local community upon its traditional system(s), because of their adaptations to stress, environment factors- both biotic and abiotic, minimizing the inherent risks associated with farming.

\section{Possible Values of Such Systems}

In terms of large-scale production, the traditional agricultural heritage systems are less competitive in products, yield and prices. Nevertheless, they have other irreplaceable functions and values, which together make them as serious alternative options/ technologies for consideration towards improvisation of available technologies and products, and in mediating the adverse consequences of climatic change, facilitating environment friendly modern development. They are:

- Rich in agricultural biodiversity in terms of products (landraces, farmers varieties) and indigenous technologies/systems for effective management and conservation of natural [both edaphic, including water (upland, midland, lowland), landscape, field, and biologicalsincluding forest, species diversity (aquatic and terrestrial)] and man-made resources 
- Possesses distinctive features of cultural, family, social, historical nature and respect for their natural surroundings and habitats

- Many are often geographically isolated to extreme climatic conditions, supporting fragile ecosystems and agriculture, based on limited natural resources (e.g. cold arid regions of Ladakh and surrounding areas in Western Himalayas and hot and arid Thar desert of Rajasthan)

- Most traditional system support conservation and sustainable use of biodiversity and genetic resources for food and agriculture

- Most provide ecosystem services for sustainability of nature and environment

- Promote conservation and sustainable agriculture based on ingenious practices, evolved over local natural resources (avoiding dependency), and provide lessons/technologies for further use, elsewhere

- Most traditional heritage system have potential for integration with modern technologies, which may help indigenous communities to make full and better use of their diverse resources

- They can serve in situ learning laboratories for demonstration of new innovative ways, facilitating sustainable agriculture and conservation of nature's bounty

\section{Need for Their Characterization, Evaluation and Protection}

All the traditional systems may not be dynamic and of the same value, either economically or for sustainability to suite the changing climatic conditions, socioeconomic development and market forces. Therefore, they need to be characterized and evaluated for assessment of their potential value. The unique AHS adapted to wide agroclimatic ranges need to be identified based on the indices discussed above and brought into scientific domain as additional resource of alternative knowledge/technique for development of more innovative agricultural technologies with a mix of components of traditional agricultural systems and the modern agricultural technologies. For example, integrated pest management systems, including both biological and chemical control, and recombinant DNA technology incorporating alien natural genes/alleles from diverse sources into locally well adapted products (varieties, breeds, etc.). This approach shall stimulate research and development of dynamic conservation practices with appropriate balance between conservation, use of modern technologies and socio-economic development.

Characterization and evaluation are also needed, because of the present scenario of Intellectual Property Rights (IPR) and access and benefit sharing (ABS) mechanism evolved as per the provisions of Convention on Biological Diversity (CBD), ensuring protection of farmers and communities rights over traditional knowledge and products, and providing fair and equitable sharing of benefit(s) accrued from their use.

Lastly, traditional heritage systems need characterization and evaluation to enable protection of important ones, before they are lost. As most are under threat because of intensification of modern agriculture with new technologies and products and following other reasons-

- Most heritage systems are being threatened, because of the population pressure, social, cultural and economic changes that are occurring to meet human and market needs without bothering about their negative impact, particularly on environment and climate.

- Accelerated urbanization and infrastructure development is adversely affecting the biodiversity in general and agrobiodiversity in particular with drastic changes in land-use pattern causing genetic erosion.

- Modernization in general and in agriculture, neglecting the traditionally diverse heritage systems evolved over time in eco-friendly manner. In this process a significant amount of traditional knowledge is being lost, needing documentation/protection.

- Reduced local community/farmers participation in planning and decision-making for the development of the area and imposition of alien ideas to obtain greater economic yield, eroding these systems and their products. 
- Inappropriate alien policies, legal and incentive framework evolved to support various initiatives, such as forest conservation and biodiversity, and water management systems (modern dams) are also putting a significant pressure on traditional heritage systems.

\section{Promotion and Utilization}

Upon evaluation and assessment of potential value, the significantly important agricultural heritage systems need to be protected, promoted and effectively utilized following diverse strategies. They may be registered/notified with appropriate agencies, along with the registration of their products (varieties, breeds, by-products, etc.) under various national and international legislations. They may be promoted with branding and encouraged with payment of incentives/ subsidies for adoption towards an environmentally friendly, and/or organic agriculture and for promotion of recycling of crop residue systems with value addition, contributing to environmental protection. Because of being labour intensive, they may provide greater employment opportunities to locals and economic development through programs, such as Agritourism, Ecotourism, Traditional Cultural tourism, etc. These programs should be evaluated following various strategies (feedback) at regular intervals to keep them updated through improvisation and dynamic changes.

\section{Epilogue}

The intensification of modern agriculture to meet the food and nutritional requirements of ever-growing global population is adversely affecting the ecofriendly traditional agricultural heritage systems, which have components both for conservation of natural resources and for sustainability of agriculture. Yield gains of modern agriculture has been threatening to the extent of extinction of traditional agriculture systems, leading to loss of knowledge about the science base of such systems and the gene pool/ genetic diversity. They also need protection as per the provisions of $\mathrm{CBD}$, to ensure protection of Indigenous Technological Knowledge (ITK) and the genetic resources evolved by generations of farmers to ascertain facilitated access and fair and equitable benefit sharing on gains accrued from their commercial use. Therefore, there is a need to identify the AHS globally, particularly in the developing world, which is still not overpowered by the modern agriculture. Scientific characterization, concentrating on interaction between companion species of agroecosystem, their documentation, and evaluation to assess the potential value is the need of the hour. This shall result in notification of potentially valuable agriculture heritage systems, development of awareness regarding their value, need for their protection and promotion for use in similar ecologies, particularly the extreme ecologies and developing economies. If this is achieved, as FAO initiative envisages in its program, these AHS can be source of scientific knowledge and genetic material for use and development of innovative technologies and products based on combination of both traditional (AHS) and modern agriculture, overcoming the challenges of changing climatic scenario and those of $21^{\text {st }}$-century. The present article discusses the criteria and methodology that can be used for identification, characterization, evaluation, protection and promotion of an AHS or its science base in overall development. The article lists 48 prospective AHS spread over the different agroecological zones of India or replicated (science base) within the subcontinent with brief description that can be the basis for their in-depth studies and use. Considering that out of the 50 GIAHS announced by the FAO by April 2018 only three are from India, the authors also take this opportunity to appeal to the national project funding agencies and the implementing institutions and research scholars to accord priority to studies on further characterization and validation of the proposed 48 Indian agricultural heritage systems to get some of them upgraded for their recognition by the FAO at the global level.

Nevertheless, as a word of caution, the authors would like to suggest that while identifying and assessing the potential value of an AHS, the usefulness of a system and the technology integral to it should not be decided by the old or new, but by its appropriateness. Also, the efforts should avoid putting the traditional against modern, but to put both together in a way to improve sustainable food production globally. 


\section{References}

Allchin F R (1963) Neolithic Cattle Keepers of South India: A Study of Deccan Ash Mounds, pp189, Cambridge University Press, New York, USA

Dandekar P (2010) Sustainable water management in Konkan under threat. In: Dams, Rivers and People. Community Water Management in Konkan - SANDRP (http:// sandrp.in/rivers/Community_Water_Management_in_ Konkan_Dec_2010.pdf)

Frawley David (2002) Vedic literature and the Gulf of Cambay discovery Bharatiya Pragna, May, pp 35-36

Globally Important Agricultural Heritage Systems (GIAHS) (2002) FAO, Food and Agriculture Organization of the United Nations, Via delle Terme di Caracalla, Rome, Italy, (www.fao.org/giahs/en/)

Gupta S P (1993) Longer Chronology of the Indus Saraswati Civilization Puratattva (1992-1993) 23 21-29

Gupta S P (2001) River Saraswati in History, Arachaeology and Geology Puratattva 31 30-38

Gupta S P (1996) The Indus-Saraswati Civilization - Origin, Problems, and Issues, Pratibha Prakashan, New Delhi, India

Jarriage J F (1984) Chronology of the earlier periods of the Greater Indus as seen from Mehrgarh. Pakistan. In: South Asian Archeology, 1981 (Ed. B Allchin) pp 21-28 Cambridge University Press, Cambridge, UK

Jayan P R and Sathyanathan N (2010) Overview of farming practices in the water-logged areas of Kerala, India Int $J$ Agric \& Biol Eng 3 1-43
Kalyanaraman S (2001) SARASWATI Babasaheb (Umakanta Keshav) Apte Smarak Samiti, Seshadripuram, Bangalore, India

Misra M K, Das P K and Dash S S (2009) Phytodiversity and Useful Plants of Eastern Ghats of Orissa with Special Reference to the Koraput Region, pp 393, International Book Distributors, Dehradun, Uttarakhand, India

Misra V N (1994) Indus Civilization and the Regvedic Saraswati. In: South Asian Archaeology, (Eds: Asko Parpola and Petted Koskikallio) pp 511-525

Mohapatra P, Dash P K, Mishra S and Sahoo D K (2009) Biodiversity Assessment in Some Selected Hill Forests of South Orissa, India Report, pp 69 Vasundhara, A/70, Sahid Nagar, Bhubaneswar, Orissa [www.vasundharaOdisha.org/ .../...]

Possehl G L (1988) Radiocarbon dates from south Asia. Man and Environment 12 169-196

Sehgal J L, Mandal D K, Mandal C and Vadivelu S (1992) Agroecological Regions of India. National Bureau of Soil Survey and Land Use Planning (NBSS \& LUP) Technical Bulletin No. 24, pp $1302^{\text {nd }}$ Edition Indian Council of Agricultural Research, Nagpur, Maharashtra, India

Singh Anurudh K (2015) Agricultural Biodiversity Heritage Sites and Systems in India pp 479, Asian Agri-History Foundation, Secunderabad, India

Singh Anurudh K (2013) Probable Agricultural Biodiversity Heritage Sites in India: XV. The Bastar Region Asian AgriHistory 17 3-24

Vanaja T (2013) Kaipad - a unique, naturally organic, saline prone rice ecosystem of Kerala, India. American Journal of Environmental Protection (AJEP) 2 42-46 doi: 10.11648/ j.ajep.20130202.12. 